\title{
Gender and norms related to an intention for participating in counseling sessions by peer educator
}

\author{
Hubungan gender dan norma dengan niat untuk berpartisipasi dalam \\ kegiatan konseling oleh pendidik sebaya
}

\author{
Ira Nurmala ${ }^{1}$, Muthmainnah ${ }^{1}$, Riris Diana $\mathbf{R}^{1}, \&$ Elisa Dwi $\mathbf{P}^{2}$ \\ ${ }^{1}$ Faculty of Public Health, Universitas Airlangga \\ ${ }^{2}$ Ngraho Health Centre, Bojonegoro \\ Address: Jl. Dr. Ir. H. Soekarno, Kampus C, Mulyorejo, Surabaya, East Java 60115 \\ E-mail: iranurmala@fkm.unair.ac.id
}

\begin{abstract}
Nowadays, drugs (narcotics, psychotropic, and addictive substances) abuse gradually increases in the adolescent group, especially High School students. Environmental impact, especially social interaction, gives a high effect on building the character in adolescents. The existence of peer-education activity is one of the promotive and preventive strategies in mitigating drug abuse. This research was done in 10 high schools in Surabaya spread over five regions (Central, North, South, West, and East). This research was quantitative with the crosssectional design while the data analysis used was a Chi-Square test with a p-value of $<0.05$ that was based on the significance level. The research finding showed that the intention of student participation was quite high, i.e. 83.1\%; from the statistical test, it had been taught that gender had a significant relationship with intention by a p-value of 0.00 . Additionally, it had also a relationship with subjective norm by a p-value of 0.00 . Conclusion: the student's norm has supported their intention to participate in the program. Meanwhile, the research finding that is based on the gender in this research showed that females had a higher intention to participate in the activity than the males had. Therefore, a conducive environment should be maintained continuously so that the positive norm can motivate the students to participate in the activity held by the peer-educator.
\end{abstract}

Keywords: gender; subjective norm; intention; peer-educator

\begin{abstract}
Abstrak
Penyalahgunaan narkoba saat ini terus mengalami peningkatan pada kelompok remaja khususnya adalah pelajar SMA. Pengaruh lingkungan terutama pergaulan memberikan dampak yang besar dalam membentuk karakter seorang remaja. Adanya kegiatan peer-education merupakan salah satu strategi promotif dan preventif mengatasi penyalahgunaan narkoba. Penelitian ini dilakukan di 10 Sekolah Menengah Atas Surabaya yang tersebar pada 5 wilayah (Pusat, Utara, Selatan, Barat dan Timur). Penelitian ini bersifat kuantitatif dengan desain studi cross sectional, analisis data menggunakan uji Chi Square dengan tingkat signifikansi p-value $<0,05$. Hasil penelitian menunjukkan bahwa niat partisipasi siswa cukup besar yaitu sebesar 83,1\%, dari hasil uji statistic diketahui bahwa variabel gender memiliki hubungan yang signifikan dengan niat dengan $p$-value $=0,00$ begitu juga dengan variabel subjective norm dengan $p$-value $=0,00$. Kesimpulannya norma yang dimiliki oleh siswa sudah mendukung niat mereka untuk berpartisipasi dalam program. Sedangkan hasil penelitian berdasarkan untuk gender dalam penelitian ini disimpulkan bahwa perempuan lebih punya niat yang tinggi untuk mengikuti kegiatan daripada laki-laki. Oleh sebab itu perlu terus diciptakan lingkungan yang kondusif agar norma yg positif dapat terus memotivasi dalam berpartisipasi dalam per-educator.
\end{abstract}

Kata kunci: gender; norma subyektif; niat; pendidik sebaya

\section{Introduction}

The development of drugs (narcotics, psychotropic, and addictive substances) abuse and illegal distribution has been a global issue and it is not limited by region and country. In addition, the global issue has threatened almost all parts of life in society. Based on the data taken from United Nations Office on Drugs and Crime (UNODC), it had been mentioned that approximately 1 out of 20 adults or one-quarter of a million people at between 15 and 64 years of age had ever used illegal drugs in 2014 (UNODC 2016). 
The impact caused by drugs abuse can lead to damages and it can be viewed from all aspects such as medical, social, law, economic, and safety. If it is viewed from a medical or health aspect, the data taken from UNODC (2016) stated that more than 29 million drug users experienced a disorder that was caused by the use of drugs. The use of drugs can cause an impact on the user's health and it can damage their body; out of 12 million people who inject the drug into their body (PWID), 14 percent of them are infected with HIV (UNODC 2016).In 2008, there were approximately 3.1 million to 3.6 million people as drug users in Indonesia or equal to $1.9 \%$ of the population at 10-59 years of age. Based on the result of a survey done by National Anti-Narcotics Agency (BNN) cooperating with Center for Health Research of University of Indonesia (UI), it was estimated that the prevalence of drug abuse in 2009 was $1.99 \%$ of Indonesian resident at 10-59 years of age. In 2010, the prevalence of drug abuse increased by a prevalence of $2.21 \%$. Furthermore, there was an increase in drug user from 2014 to 2015 by $0.05 \%$ with a prevalence rate of drug use of 4.098 .029 people from the total population in Indonesia at 10-59 years of age (Prayoga 2015).

Based on the Health Information Data by the Ministry of Health of the Republic of Indonesia in 2014, the result of a survey that had been done by National Anti-Narcotics Agency (BNN) and Indonesian National Police (POLRI) in 2013 showed that East Java was at the first rank for the total drug abuse case based on province level in the 3 consecutive years i.e. 2010, 2011, and 2012 (Kementerian Kesehatan RI 2014). An adolescent is a group of people that has a risk of being a target for the drug dealer. Adolescence is a dangerous period of life because, during that period, a person is at a transition period, from childhood to the next phase i.e. adulthood period. This period can be considered as a critical period since they have no guidance, while their character is being structured (Soekanto 1990). In the period to find a self-identification, a teenager can be easily affected by the environmental interaction around them. Based on the data taken from BNN within a period of 2008-2012, it has been recorded that the biggest proportion of drug-related crime was High School students (Kementerian Kesehatan RI 2014).

Surabaya is a capital city of East Java Province. In this city, it has been recognized that 84 students in this province, in 2016, had been become drug users and they underwent a rehabilitation process. In 2017, that number increased by 101 students; those students were addicted to double L/ Trihexyphenidyl (a type of drug). The detail is 4 Elementary students, 63 Junior High students, and 34 High School students. Based on the data taken from BNN and Polri in 2013, it was known that the number and the proportion for drug-related crime, both Indonesian citizen and foreign citizens, was dominated by males i.e. above $80 \%$. Within $2008-2012$, the number of drug-related crime from Indonesian citizen had the lowest proportion for male i.e. $89.94 \%$ in 2011 and the highest proportion i.e. $92.48 \%$ in 2008 (Kementerian Kesehatan RI 2014).

Likewise, in 2016, the data from a survey done by $B N N$ showed that males had more risk in using drug than female did. Male to female ratio for using the drug is approximately $4: 1$. This pattern did not change relatively in the last decade. The number of prevalence for the male that ever uses the drug is $13.7 \%$ and female is $3.3 \%$ (2006), while in 2016 , the percentage changed into $6.4 \%$ for male and $1.6 \%$ for female (Prayoga 2015).

The adolescent student spends their time around eight hours a day. Therefore, there is a preventive and promotive activity at school that is very important to prevent the students from deviant behavior. The school activity that can be done is health education. It aims to change a person's behavior or society from unhealthy behavior into health behavior (WHO 1986). This activity can be performed through various methods; the methods are divided into three types i.e. individual method group method, and mass method (Notoatmodjo 2012). Health education among the students can be in form of a peer-educator program: a program that can be done starting from the students, by the students, and for the students. In adolescence, someone will easily put their trust on their friends rather than their parents, family or teachers. Peer-educator program that is an initiation program at senior high school level will play a vital role in structuring the behavior of adolescent students. This program has an important role in providing factual knowledge to their peers and it is equipped with clear 
information on the preventive action and the possible result of drug abuse. In addition, this program has a function to help their peers in performing self-development activity to recognize themselves as an attempt to seek their self-identity.

The behavioral theory according to Ajzen (1991), stating that an intention to behave is determined by three determinant factors i.e.: 1) An attitude towards a behavior; 2) Subjective norm; and 3) Perceived behavioral control (Ajzen 1991). Those three factors are affected by background factors such as gender, age, religion, occupation, knowledge, etc. The existence of a peer-education program at school cannot be performed successfully without any support from the school community especially students, which are the target of the program. Peer-educator program is strongly related to counseling sessions or interpersonal discussion in overcoming personal problem; it can be seen that the habit of sharing their story is dominantly done by females. Additionally, subjective norm owned by a student can be a strong predictor to determine someone's behavior. Based on those backgrounds, this research aimed at knowing and analyzing the relationship between gender and a subjective norm in Senior High School students toward an activity held by peer-educator.

\section{Research Method}

This research is observational research using the cross-sectional study as the research design. Observational research is a non-experimental research that researcher have no intervention to the variables in the research (Jasaputra \& Santosa 2008). It is descriptive quantitative research. This research was done within July-August 2018. The research location was at five regions of Surabaya i.e. the central region, west region, east region, north region, and south region with 10 school samples comprising SMAN 5 Surabaya, SMKN 5 Surabaya, SMAN 14 Surabaya, SMAN 15 Surabaya, SMAN 16 Surabaya, SMKN 10 Surabaya, SMAN 19 Surabaya, SMAN 22 Surabaya, SMA Barunawati, and SMA Hidayatul Ummah. The selection of the schools was done based on the inclusive criteria determined by the researcher i.e. a school that has some students acted as peereducator. The population in this research was all non-peer-educator students at $11^{\text {th }}$ grade and $12^{\text {th }}$ grade. Sampling was done using simple random sampling. The total sample as the respondent was 854 people collected by using Lemeshow formula.

In this research, there are two variables i.e. dependent variable and independent variable. The respondent's intention to participate in the peer-education program was the dependent variable while gender and subjective norm were the independent variables.

The primary data collection was done using a questionnaire as the instrument that was adjusted to the research topic. Before conducting the data collection, the researcher conducted validity test and reliability test that were done to 20 people that had similar characteristic to the research respondent. Before the respondent filled out the questionnaire, the researcher read PSP (Panduan Sebelum Persetujuan/ Informed Consent) aloud and gave the informed consent as a statement expressed by the respondent that they agreed to be a part of this research as a respondent. The questionnaire that should be filled out by the respondents including: 1) Self-identity comprising age, address, and gender, 2) Subjective norm: the students as the respondents were asked to answer four questions on the support for surrounding environment toward an activity held by a peer-educator, 3 ) intention: the students as the respondents were asked to answer a question on how far a plan that will be made to participate in an activity held by a peer-counselor in form of both sharing or discussion.

After the data collection had completed, the researcher conducted editing, coding, entry, and cleaning. For subjective norm, if the respondents answer: strongly correct scored 4, correct scored 3, incorrect or false scored 2, strongly incorrect scored 1. Subjective norm was divided into 4 categories i.e. strongly agree, agree, somewhat agree, and disagree. Meanwhile, the intention was divided into 2 categories i.e. having an intention to participate and having no intention to participate in an activity held by the peer-educator. Data analysis was done using a statistical test called a Chi-Square test with a p-value of $<0.05$. Data analysis is used to find the relationship between subjective norm and intention to partipated; and the relationship between gender and intention to participated. 
Conclusions were also verified during the study. Conclusions are drawn when researchers organize records, patterns, statements, configurations, causal directions, and various propositions (Mantja 2007). Ethics approval was received from the Faculty of Nursing, Universitas Airlangga with the certificate number 940-KEPK.

\section{Results and Discussion}

Table 1.

Frequency Distribution of the Respondent's Demographic Characteristic in 2018

\begin{tabular}{lcc}
\hline Respondent's age & Frequency $(\mathbf{n})$ & Percentage (\%) \\
\hline 15 years old & 72 & 8.4 \\
16 years old & 429 & 50.2 \\
17 years old & 305 & 35.7 \\
18 years old & 43 & 5.0 \\
19 years old & 5 & 0.6 \\
Total & $\mathbf{8 5 4}$ & $\mathbf{1 0 0 . 0}$ \\
\hline
\end{tabular}

Source: Primary Data

The frequency distribution of the respondent's demographic characteristic was seen from the age. The respondent's age was calculated by their birth year until this research was being conducted. Based on table 1, it is known that the range of the respondents' ages is at 15-19 years of age and the biggest percentage at 16 years of age is $50.2 \%$.

Table 2.

The Crosstab of Gender Toward An Intention to Participate in Activity Held by the Peer-Educator in 2018

\begin{tabular}{|c|c|c|c|c|c|c|}
\hline \multirow{3}{*}{ Gender } & \multicolumn{4}{|c|}{$\begin{array}{l}\text { The intention to participate in } \\
\text { activity held by the Peer-Educator }\end{array}$} & \multirow{2}{*}{\multicolumn{2}{|c|}{ Total }} \\
\hline & \multicolumn{2}{|c|}{ Yes } & \multicolumn{2}{|c|}{ No } & & \\
\hline & $\mathrm{n}$ & $\%$ & $\mathrm{n}$ & $\%$ & $\mathbf{n}$ & $\%$ \\
\hline Female & 429 & 87.4 & 62 & 12.6 & 491 & 100.0 \\
\hline Male & 281 & 77.4 & 82 & 22.6 & 363 & 100.0 \\
\hline Total & 710 & 83.1 & 144 & 16.9 & 854 & 100.0 \\
\hline
\end{tabular}

Based on Table 2, it is known that the female students have a higher percentage for an intention to participate in an activity held by peer-educator than the male students have. It happens due to the proportion of female and male students. The total female student is higher than the total of male students. The result of a statistical test using Chi-Square test, it was obtained a p-value of 0.000 (p-value $<0.05$ ); it can be defined that there is a significant relationship between gender and the intention to participate in an activity held by the peer-educator as a preventive attempt of drug abuse.

The result of the analysis showed that there was a relationship between gender and the intention to participate in an activity held by the peer-educator such as sharing, discussion, and the like. It was shown that the female respondents had a high level of concern on maintaining their health. Females prefer to share their story to their friends rather than the males do. The males tend to have no concern or introvert toward their problems. One of the roles of the peer-educator is helping their peers to solve their problems. The females tend to care toward what has happened to themselves and they tend to show their effort to improve their health. Meanwhile, the characteristic of males in seeking help is extremely low (Papalia 2009). The characteristics of female adolescents psychologically have a faster change and maturity development than the males have; it becomes a factor of causing the female students to tell their story to their parents, family, or teachers so that they are comfortable and more open with their peers about their personal problems. The research finding after collecting the data also found 
that females tended to have face to face activities more or interpersonal communication with their friends. In contrast with males, they preferred gathering in a big group, so they had less possibility of having a sharing or a discussion related to their personal problem. Besides, the norm formed around the high school students is that females are considered as a common to do sharing activity compared to males. Meanwhile, males who perform the sharing activity are considered as uncommon since it is related to their masculinity. In fact, there was no difference based on gender at school for participating in the peer-education program. An intention is a cognitive representation from someone's readiness for conducting a certain behavior and it is considered as the closest antecedent to a behavior. Personality, age, gender, and culture are some factors that can affect the intention (Ajzen 1991).

Females behave gently, able to read emotions better, and they are considerate toward a situation and others' feelings (Friedman 2008). They tend to obey the rules applicable in society to stay away from or prevent drug abuse. In addition, females have more positive behaviors towards the prevention of HIV/AIDS than males have; it is based on the result of a statistical analysis that shows a p-value of $0.001<\alpha(0.05)$ (Sofni, Dewi, \& Novayelinda 2015). Women tend to have higher intention in entrepreneurship activity than men have (Adi, Sumarwan, \& Fahmi 2017).

Along with research that has been done, it was shown that hypothesis testing had a significant value ( $p$-value $=0.001$ ) on the relationship between gender and political participation; females had a participation level of $55.05 \%$, while males had a participation level of $44.95 \%$ (Handayani 2017). In relevant to another research, it has been stated that gender has a strong relationship with the participation level of society, in form of the aspect of the idea, rather than other two variables i.e. age and the duration of living. It happens because of the majority of the people who participate in a meeting for maintaining the environmental drainage is men (males), so that the role of women (females), in this case, becomes passive (Jatmiko 2017). Gender is strongly related to the intention to participate significantly yet females or males who have the intention to participate highly depend on the activity they will take part.

Females need more support on the social aspect. Therefore, the participation in peer-education activity is highly dominated by females. Social support that is needed by females is information support and emotional support. Through peer-education activity, female students obtained some supports in form of important information on the prevention of drug abuse and the current issue occurred in the society. The emotional support became the second-rank support needed by females after the information support; it happened due to the natural characteristic of females i.e. the creatures that rely more on feelings/emotions (Tyas 2014).

Emotional support comprises empathy, attention given by other people in form of belief and care. They tend to show that they need a higher level of social support than the emotional support compared to the males do. Male students tend to not to care; besides, male students are not comfortable to talk to the female students. Therefore, in the caderization, the school authorities should pay attention to the system for selecting the students to be peer-educators evenly, both males and females, by concerning on the proportion of the total students at the school. However, gender equality is needed in order to make the males and females have a similar intention to participate in peer educator activity and the proportion between males and females is balanced. Gender issue often corners the females as people who have more unstable emotion than the males have. Thereby, a problem-solving related to gender is needed. It can be done by empowering or promoting gender equality especially in the public health field (Susanti 2018). Many health programs make females as the target. Yet, it is not optimal as stated in another research that the health program that has been conducted is not optimal yet, so that the improvement on the target of the program i.e. female people, is needed (Annisa \& Nurmala 2018).

Based on Table 3, it is known that the subjective norm owned by the respondents is mostly at the positive category i.e. agree and strongly agree, yet there are many respondents who have subjective norm at negative category i.e. disagree or somewhat agree. From the result of the crosstab, it was known that the biggest percentage of intention to participate in an activity held by the peer-educator 
was the respondents who have subjective norm at positive category. The result of the analysis obtained from a Chi-Square test was a p-value of 0.00 (p-value $<0.05$ ); therefore, it could be defined that there was a significant relationship between subjective norm and the intention to participate in an activity held by the peer-educator as a preventive attempt of drug abuse.

Table 3.

The Crosstab of Subjective Norm Toward The Intention to Participate in An Activity Held by The Peereducator in 2018

\begin{tabular}{|c|c|c|c|c|c|c|}
\hline \multirow{3}{*}{ Subjective norm } & \multicolumn{4}{|c|}{$\begin{array}{l}\text { The intention to participate in } \\
\text { activity held by the Peer-Educator }\end{array}$} & \multirow{2}{*}{\multicolumn{2}{|c|}{ Total }} \\
\hline & \multicolumn{2}{|c|}{ Yes } & \multicolumn{2}{|c|}{ No } & & \\
\hline & $\mathbf{n}$ & $\%$ & $\mathbf{n}$ & $\%$ & $\mathbf{n}$ & $\%$ \\
\hline Disagree & 20 & 52.6 & 18 & 47.4 & 7 & 100.0 \\
\hline Somewhat agree & 211 & 71.3 & 85 & 28.7 & 83 & 100.0 \\
\hline Agree & 437 & 91.6 & 40 & 8.4 & 581 & 100.0 \\
\hline Strongly agree & 42 & 97.7 & 1 & 2.3 & 183 & 100.0 \\
\hline Total & 710 & 83.1 & 144 & 16.9 & 854 & 100.0 \\
\hline
\end{tabular}

The norm that was formed by the high school student in Surabaya has been good i.e. inviting an informant to conduct socialization, some schools have cooperated with Civil Society Organization to conduct urine tests to the students, and various presentations containing information on mass media could also form a norm that drug should be avoided. Some schools assigned the students to make a message about health promotion related to the prevention of drug abuse. The research finding showed that there was a significant relationship between subjective norm and intention. A positive attitude can prevent premarital sexual behavior is determined by subjective norm and perceived behavioral control owned by adolescents. In general, perceived behavioral control in adolescents is not strongly good (Mahfiana 2009).

Subjective norm is a factor that can affect the consumer's purchasing intention to buy a product (Hirunpattarasilp \& Udomkit 2011). In line with the research finding, it is stated that subjective norm gives a positive impact on someone's intention in performing a behavior (Komsi 2013). This is also relevant to a research stating that subjective norm significantly gives a positive impact on the compliance toward corporate tax (Aryadhe \& Sudiksa 2018); another research also stated that subjective norm and self-efficacy give a positive impact on college student's interest in entrepreneurship; this is based on the result of multiple regression analysis techniques (Sarwoko 2011). Subjective norm partially and simultaneously gives a positive impact on intention (Wahyuni, Basri, \& Shabri 2017). It is also relevant to a research stating that there was a significant relationship between subjective norm and reporting intention ( $\mathrm{p}$-value $=0.000$ ) with $\mathrm{OR}$ value of 17.48 ; it means that someone who has a negative subjective norm is a risk to intention to be. 17.4 times weaker than someone who has a positive subjective norm (Suprapto 2017). It is different from another research mentioning that the result of hypothesis testing showed an insignificant value ( $\mathrm{p}$-value $=0.40$ ) so that it did not represent the population condition even though the relationship between subjective norm and intention was quite strong (Subari, Djuhaeni, \& Wiwaha 2014). Another research mentioned that there was a nearly significant relationship between subjective norm and the increase of the cadre's intention in the activity of finding a case (Aderita \& Chotimah 2018). To increase the subjective norm in students, the school authorities should perform an evaluation and monitoring the activity of peer-education.

In structuring this norm, the role of family is very important; the school authorities should cooperate with parents to provide an understanding to the adolescents that the peer-educator activity provides a benefit to them. The factor of the family environment and the environment around the students are significantly proven that it can affect the students' intentions to participate in entrepreneurship. 
Besides family, another component that will affect subjective norm is peer group or social interaction. Parental supervision should be increased in monitoring and supervising the adolescents to be at an environmental interaction that is non-deviant. The impact of a peer group plays an active role in determining someone's attitude (Li \& Naeem 2011). If an environmental interaction gives a good impact, the students will have a good attitude toward a behavior.

Therefore, to form a high intention in high school students, the cooperation will all parties is needed to create a conducive environment. A school needs to conduct a meeting for parents/custodian in order to get more supports for peer-education activity. Then, the schools should conduct regular training, for the peer-educator, that does not contain only information on drug prevention but it also contains the way of communication or interpersonal approach to an individual; the goal is that the peer-educator can obtain a trust so that they are able to invite their peers to participate in an activity that has been made; this aims to prevent the drug abuse. In addition, the school authorities can provide information access on peer-education activities and provides a policy in form of giving an additional score or credit points for the students who participate actively in peer-education activity.

It happens since there is less personal belief on the thing that should be done and the individual belief on the thing that is expected by other people or people who are precious for them (Fishbein \& Ajzen 1975). It was also supported by a previous study revealing that subjective norm had no relationship between intention to be active in physical activity, yet it had a relationship toward an attitude toward behavior and perceived behavioral control that provided a motivation to an active intention in physical activity so that it is categorized in positive category (Hagger, Chatzisarantis, \& Biddle 2002).

Subjective norm, in this case, consists of a belief towards an applicable norm in society on preventing premarital sex and the respondent's motivation to comply with the norm or regulation (Ajzen 1991). A belief towards a norm can be shown by the respondent's compliance to comply with all social norms that are applicable in society. Even though the social norm in the society has shifted, most of the respondents still believe that commands and prohibitions from both family and teachers should be obeyed. This research finding is relevant to another research proving that subjective norm has a positive and significant impact on the intention of a hotel in paying tax (Kusumawati, Halim, \& Said 2014). Another research also shows that subjective norm has a positive and significant impact on an intention to purchase green food (Ham, Jeger, \& Ivković 2015).

\section{Conclusion}

The conclusion that can be drawn from this research is both gender and subjective norm have a significant impact on an intention to participate in an activity performed by the peer-educators. Females have a higher intention than males (female respondent is $87,4 \%$ and the male respondent is only $77,4 \%$ ) because females tend to need higher social support, especially emotional support than the males do. The norm that is formed around the students shows that females commonly participate in sharing activity. In contrast, the males are considered uncommon to participate in the activity since it is related to their masculinity. Additionally, it can be concluded that the students are more comfortable to tell their story to someone who has a similar gender. Therefore, the school needs to pay attention to the proportion of gender (male and female students) when the caderization is performed. Subjective norm at school should be continuously maintained to create a conducive environment such as an information access on drug and peer-education program, conducting a regular training of trainer for the peer-educator, the regulatory enforcement on drug abuse, and implementing the school policy on peer-education program in form of school extracurricular activities or it can be in form of giving an additional score or credit points for the students who are actively involved in peer-education activity.

\section{Acknowledgement}

Acknowledgments to Universitas Airlangga Surabaya which funded this research, to schools from Senior High Schools in East Surabaya City, Central Surabaya, West Surabaya, South Surabaya and North Surabaya who had given permission for the ongoing research, and to informants who were happily sharing their experiences about the peer educator program. 


\section{References}

Aderita NI \& Chotimah C (2018) Peran kader kesehatan dalam tindakan penemuan kasus Tuberkulosis dengan pendekatan theory planned of behaviour di wilayah kerja Puskesmas Bendosari. IJMS-Indonesian Journal on Medical Science 5 (2):160-167.

Adi F, Sumarwan U, \& Fahmi I (2017) Literasi keuangan syariah dan konvensional terhadap minat berwirausaha pada mahasiswa. Jurnal Al-Muzara'ah 5 (1):1-20.

Ajzen I (1991) The theory of planned behavior. Organizational Behavior and Human Decision Process 50:179-211.

Annisa FN \& Nurmala I (2018) Influence perceived benefit and perceived self efficacy with intention of adolescent girls in consuming fe tablet. Indian Journal of Public Health Research and Development (IJPHRD) 9 (4). https://doi.org/10.5958/0976-5506.2018.00307.8.

Aryadhe AST \& Sudiksa IB (2018) Pengaruh sikap dan norma subjektif terhadap niat beli dan keputusan pembelian. E-Jurnal Manajemen Unud 7 (3):1452-1480.

Fishbein M \& Ajzen I (1975) Belief, attitude, intention and behavior: An introduction to theory and research. Contemporary Sociology 6. https://doi.org/10.2307/2065853.

Friedman H (2008) Kepribadian Teori Klasik dan Riset Modern Jilid 2 (1st-37th ed.). Jakarta: Erlangga.

Hagger MS, Chatzisarantis NLD, \& Biddle SJH (2002) The influence of autonomous and controlling motives on physical activity intentions within the theory of planned behaviour. British Journal of Health Psychology 7 (3):283-297. https://doi.org/10.1348/135910702760213689.

Ham M, Jeger M, \& Ivković AF (2015) The role of subjective norms in forming the intention to purchase green food. Economic Research-Ekonomska Istrazivanja 28 (1):738-748. https:// doi.org/10.1080/1331677X.2015.1083875.

Handayani V (2017) Hubungan jenis kelamin dan tingkat pendidikan dengan partisipasi politik dalam pemberian suara pada PILKADA serentak tahun 2015 di Desa Mamahak Besar Kecamatan Long Bagun Kabupaten Mahakam Ulu. EJournal Pemerintahan Integratif 5 (4):488-496.

Hirunpattarasilp T \& Udomkit N (2011) Factors affecting consumers' purchasing decisions on CSR banking: A case of commercial bank in Thailand. RJAS 1 (1):27-34.

Jasaputra DK. \& Santosa S (2008) Metodologi Penelitian Biomedis (Edisi 2). Bandung: Danamartha Sejahtera Utama (DSU).

Jatmiko YA (2017) Pengaruh karakteristik masyarakat terhadap partisipasi pemeliharaan saluran lingkungan di Desa Bandungrejo, Kecamatan Mranggen, Kabupaten Demak. Jurnal Pembangunan Wilayah \& Kota 13 (2):257-268.

Kementerian Kesehatan RI (2014) Buletin Jendela Data dan Informasi Kesehatan, (semester 1).

Komsi K (2013) Analisis pengaruh faktor eksternal dan internal terhadap minat berwirausaha. Proceeding PESAT 5 (1998):1-7. https://doi.org/10.1016/j.infbeh.2006.05.002.

Kusumawati A, Halim A, \& Said D (2014) Effects of intention mediation towards attitude, subjective norms and perceived behavioral control on taxpayers' behavior. Journal of Research in Business and Management 2 (10):26-32.

Li Z \& Naeem M (2011) Factors affecting attitudes: A study of immigrants' attitude towards the brochures and website of Växjö Kommun. http://www.diva-portal.org/smash/record. jsf?pid=diva2:421520.

Mahfiana L (2009) Remaja dan Kesehatan Reproduksi. Ponorogo: Center for Religion and Sexuality.

Mantja W (2007) Etnografi Desain Penelitian Kualitatif Pendidikan dan Manajemen Pendidikan. Malang: Elang Mas. 
Notoatmodjo S (2012) Promosi kesehatan dan Perilaku Kesehatan. Jakarta: Rineka Cipta.

Papalia E (2009) Human Development: Perkembangan Manusia. Jakarta: Salemba Humanika.

Prayoga R (2015) BNN: Transaksi Narkoba Indonesia Tertinggi se-ASEAN. ANTARA News. https:// www.antaranews.com/berita/474528/bnn-transaksi-narkoba-indonesia-tertinggi-se-asean

Sarwoko E (2011) Kajian empiris entrepreneurship intention mahasiswa. Jurnal Ekonomi Bisnis 16 (2):126-135. https://doi.org/10.1177/0149206307302552.

Soekanto S (1990) Sosiologi Suatu Pengantar. Jakarta: PT Raja Grafindo Persada.

Sofni LM, Dewi YI, \& Novayelinda R (2015) Perbandingan pengetahuan dan sikap antara remaja putra dan putri tentang tindakan pencegahan HIV/AIDS. Jom 2 (2):1241-1249. https://media. neliti.com/media/publications/188676-ID-perbandingan-pengetahuan-dan-sikap-antar.pdf.

Subari EDM, Djuhaeni H, \& Wiwaha G (2014) Analisis Faktor-faktor yang memengaruhi intensi masyarakat Kota Cirebon menjadi peserta mandiri jaminan kesehatan. http://pustaka.unpad. ac.id/wp-content/uploads/2015/02/Analisis-Faktor-Faktor-Yang-Memengaruhi-IntensiMasyarakat-Kota-Cirebon.pdf.

Suprapto SW (2017) Hubungan Sikap, Norma Subjektif, Persepsi Kontrol Perilaku dan Pengetahuan Terhadap Intensi Pelaporan Kecelakaan Kerja Perawat Rawat Inap Tulip dan Melati di Rumah Sakit X Kota Bekasi Tahun 2016. Universitas Islam Negeri Syarif Hidayatullah Jakarta.

Susanti E (2018) Unequal gender relations in the practices of girl marriage in poor families at East Java Province. Masyarakat, Kebudayaan dan Politik 31 (4):440-450.

Tyas HA (2014) Perbedaan Kebutuhan Dukungan Sosial Antara Laki-laki dan Perempuan Pada Pasien Penderita Gagal Ginjal di RSUD Dr. Moewardi. Surakarta.

UNODC (2016) World Drug Report.

Wahyuni D, Basri H, \& Shabri M (2017) Pengaruh Sikap, Norma Subjektif, Perceived Behavioral, (July 2018).

WHO (1986) Ottawa Charter for Health Promotion. https://doi.org/10.1093/heapro/1.4.405. 